\title{
First report of natural infection of tomato yellow leaf curl virus on cucumber in China
}

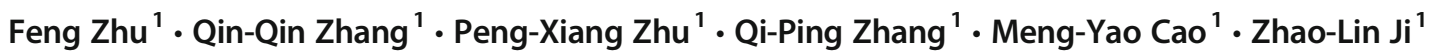

Received: 17 July 2020 / Accepted: 26 August 2020 / Published online: 31 August 2020

(C) Società Italiana di Patologia Vegetale (S.I.Pa.V.) 2020

Keywords Tomato yellow leaf curl virus $\cdot$ Cucumis sativus . China

Tomato yellow leaf curl virus (TYLCV) is one of the major threats to tomato production in China. This virus was first reported in 2006 on tomato in China (Wu et al. 2006). In June of 2019, virus-like symptoms such as yellowing, mosaic and curling of leaves were observed in cucumber (Cucumis sativus) plants in Yangzhou city in Jiangsu Province in China. Leaf samples were collected from five symptomatic cucumber plants. All samples were assayed by double-antibody sandwich (DAS)-ELISA (Qiaodu, Shanghai, China) (Ji et al. 2019) for TYLCV. Results revealed that the five samples were positive for TYLCV. DNA was extracted from leaf samples of five symptomatic cucumber plants. PCR was performed using forward primer (5'-CACAGAGTCGGTAAGAGG-3') and reverse primer (5'-CATACACTGGATTAGAGGC-3'), which were designed to amplify a partial coat protein gene of TYLCV (GenBank accession number DQ139329). The expected $421 \mathrm{bp}$ amplicons were amplified from the five symptomatic leaf samples that were positive for TYLCV in DAS-ELISA. The DNA products were purified by TIANgel Midi Purification Kit (Tiangen, Beijing, China) and cloned into the pMD19-T vector (TaKaRa, Dalian, China) and sequenced (MT862130). Nucleotide BLAST analysis revealed that the sequence had $99.52-100 \%$ nucleotide identity to several TYLCV isolates for which sequences are available in GenBank (MN053910, MK386676, MG770210, KX440607, KY640456). On the basis of the data from serological and molecular analyses, the virus associated with yellowing and curling of cucumber plants was identified as TYLCV. To our knowledge, this is the first report of TYLCV in cucumber plants in China.

Acknowledgements This work was supported by the Qing Lan Project of Yangzhou University and the earmarked fund for Modern Agro-industry Technology Research System (CARS-30-3-02).

\section{Compliance with ethical standards}

Conflict of interest The authors declare that they have no conflict of interest.

Research involving human participants and/or animals This article does not contain any studies with human participants or animals performed by any of the authors.

Informed consent This manuscript is new and not being considered elsewhere. All authors have approved the submission of this manuscript.

\section{References}

Ji ZL, Zhu PX, He GH, Liao YH, Zhu F (2019) First report of tobacco rattle virus in hydrangea in China. J Plant Pathol 101:1259-1260

Wu JB, Dai FM, Zhou XP (2006) First report of tomato yellow leaf curl virus in China. Plant Dis 90:1359

Publisher's note Springer Nature remains neutral with regard to jurisdictional claims in published maps and institutional affiliations.
Feng Zhu

zhufeng@yzu.edu.cn

College of Horticulture and Plant Protection, Joint International Research Laboratory of Agriculture and Agri-Product Safety, the Ministry of Education of China, Yangzhou University,

Yangzhou 225009, Jiangsu, China 